\title{
Empowering Africa: normative power in EU-Africa relations
}

Sibylle Scheipers and Daniela Sicurelli

'Europe has a strong interest in a peaceful, prosperous and democratic Africa. Our strategy is intended to help Africa achieve this.' (Council of the European Union 2005)

\section{Introduction}

Africa is often referred to as the 'forgotten continent' in which most international actors do not have a vested interest. Its Sub-Saharan part is the poorest and least developed area in the world. ${ }^{1}$ Moreover, it is the world's most conflict-ridden region. Against this background, the EU's role in Africa is outstanding: the EU is the biggest export market for African products and the biggest donor of development aid. Partly, this stems from the traditionally strong bilateral links between individual EU member states and African countries due to their colonial history. During its EU Presidency in 2005, Britain, for instance, made strong efforts to turn African development into a key issue on the EU foreign policy agenda. Since the adoption of the Lomé Convention in 1975, the EU has a formal relationship with Sub-Saharan African states within the larger framework of the African, Caribbean and Pacific countries (ACP). ${ }^{2}$ In recent years, however, the EU increased its efforts to build stronger ties with Africa beyond the ACP framework. In 2000, the first EU-Africa Summit took place in Cairo. A second summit is scheduled for 2007 in Lisbon. In addition, in 2005 the Council of the European Union published the 'EU-Africa Strategy' in which it sets out a framework for reaching the UN Millennium Development Goals in Africa.

The EU's conduct of its foreign policy has been analysed as an attempt to construct its image as a normative power in international relations (Manners 2002). The theoretical conceptualization and the empirical research on normative power Europe tended to emphasize - and criticize - the EU's missionary zeal and its propensity to 'inferiorize' outsiders in order to bolster its self-esteem (Diez 2005). Yet the EU engages in a rhetoric of partnership, solidarity and dialogue towards Sub-Saharan Africa. Thus, EU-Africa relations are an excellent framework in which to investigate an aspect of the EU's normative power that did

1 According to 2006 UNDP Human Development Ranking, 38 out of the 50 least developed states in the world are located in Sub-Saharan Africa, URL <http://hdr.undp.org/hdr2006/statistics/> (accessed 26/04/2007).

2 We restricted the geographical scope of our investigation to Sub-Saharan African states, which are part of the ACP framework, whereas most North-African states are part of a different framework, the EuroMediterranean Partnership (EMP). This is arguably not without difficulties. Most notably, African states themselves are not particularly happy about this artificial boundary. 
not receive much attention yet: the EU's efforts to empower others while endeavouring to promote its core values internationally.

In this article, we will focus on two cases in which the EU attempts to advance its values internationally. First, the EU promotes the International Criminal Court (ICC) within the framework of its Common Foreign and Security Policy (CFSP), thereby emphasizing its commitment to human rights. Secondly, the EU aims to disseminate the norm of environmental protection by supporting the Kyoto Protocol. We will provide empirical evidence that in both cases, the EU made efforts to empower Sub-Saharan African countries on three levels. The identity level seems to be most crucial in that support for both international institutions on the part of African states increases their recognition in the eyes and in the rhetoric of European officials. Second, at the knowledge level, the EU supports Sub-Saharan African states by providing legal and technical expertise in order to enable them to participate in international negotiations and to implement international agreements. Finally, the EU provides material incentives (material level) within the framework of conditionality arrangements. However, whereas the first two levels are part of the EU's official selfportrayal, it tends to keep quiet about the provision of material incentives, since they seem to contradict its rhetoric of EU-Africa relations as a partnership on an equal footing.

The reminder of this article is structured as follows: the next section is devoted to a critical discussion of the concept of normative power with a particular view to the modes of identity construction it involves. We will then move on to our case studies on the ICC (part 3) and on the Kyoto Protocol (part 4). In the fifth part, we will summarize our findings and discuss what insights the investigation of EU-Africa relations offers with respect to our understanding of the EU as a normative power.

2. Normative power EU: disempowering and empowering

The EU's normative power is understood as a practice by which the EU seeks to spread its core norms, such as human rights, democracy, rule of law and environmental protection, internationally. According to Ian Manners, the distinctive feature of the concept of normative power is that it refers to a specific form of power: “"power over opinion”, idée force, or “ideological power”' (2002: 239). Normative power is thus defined as the 'ability to shape conceptions of “normal” in international relations' (ibid.). The concept of normative power shares some traits of the older notion of 'civilian power' (cf. Maull 1990; Hill 1990; Duchêne 1973) in that it indicates a predisposition for the use of non-military instruments in foreign policy, a preference for non-coercive means - 'carrots' rather than 'sticks' - and a firm 
commitment to multilateralism (cf. Sjursen 2006b: 172). ${ }^{3}$ Even though the EU acquired military capabilities within the framework of the European Security and Defence Policy (ESDP), this does not necessarily undermine its role as a normative power - as long as military means are not prioritized over non-military ones (Manners 2006a). Moreover, the EU's role as a normative power is related to its distinctive nature as a political organization. The EU is not a state. Rather, it is a post-Westphalian entity and as such it is also characterized by distinctive decision-making processes (Manners 2002: 240f.).

The practice of 'othering' has received much attention as an activity by which EU officials construct the EU's identity as a normative power while at the same time exerting power in its external relations. 'Othering' refers to the demarcation of the self against a - threatening, inferior or simply different - other (Diez 2005: 628; Rumelili 2004). Thus, othering is a practice by which the EU constructs its identity, but it is also a transformative action with very 'real' consequences. Securitization, i.e. the continued depiction of an 'other' as threatening to the own political community, may result in military action (Wæver 1995). The EU's policy towards Turkey is underpinned by the notion that Turkey represents the EU's 'other' inasmuch as its human rights record does not live up to the standards and requirements set out in the Copenhagen criteria (Diez 2005: 632, 2004). Finally, the EU's behaviour on the matter of the Kyoto protocol and the ICC in transatlantic relations are guided by the idea that the US is lagging behind in the implementation of universal values of human rights and environmental protection (Scheipers and Sicurelli 2007).

In all the examples quoted above, othering has a strong connotation of disempowering the other while at the same time empowering the self - the EU - inasmuch as the other is depicted as inferior. ${ }^{4}$ This, however, is only one form in which othering can occur. The aim of our article is to investigate a different practice in the context of the EU's role as and its exertion of normative power; namely, the extent to which the EU empowers other actors. The concept of empowering has a strong link with social relations of constitution. It is related to the idea of 'power to' rather than 'power over':

'Concepts of power rooted in behaviour and interaction point to actors' exercise of control over others; they are, then, "power over" concepts. Concepts of power tied to

3 The debate about normative power encompasses different views on how normative power and civilian power are related. Manners stresses that normative power is different from civilian power, because the latter neglects the importance of ideas and norms (2006b: 175ff., 2002: 240). Diez argues that 'civilian power can be read as one specific form of normative in that at its heart lie particular kinds of norms (namely civilian)' (2005: 617), whereas Sjursen uses the terms normative power and civilian power almost interchangeably (2006a,b).

4 It should be noted, however, that discourses of othering have a dynamic of their own and can therefore also result in empowering rather than disempowering the other. If Turkey improves its human record, for instances, it can in turn demand to be granted access to the EU (cf. Diez 2005: 633). 
social relations of constitution, in contrast, consider how social relations define who the actors are and what capacities and practices they are socially empowered to undertake; these concepts are, then, focused on the social production of actors' "power to".' (Barnett and Duvall 2005: 46).

As with othering in general, empowering is identity-based, but in contrast to disempowering the 'other', it aims at increasing the recognition and the international status of a third country or actor by, for instance, depicting it as equal or even similar to the 'self'. The practice of empowering is not restricted to discourses of identity construction. Rather, it involves a variety of practices and power resources, such as the transfer of knowledge and expertise, the provision of enhanced development chances and/or trade opportunities and the transfer of material resources. Moreover, empowering others does not happen for merely altruistic reasons. Most often it empowers the providing as well as the receiving end. A donor of development aid, for instance, also profits from providing aid in that his or her international recognition increases. Empowering others can also be pursued for strategic reasons, for instance, an actor A can aim at increasing the stability of a country or a region B the instability of which would be detrimental to A's interest. Finally, empowering others is not necessarily a morally good thing. Ultimately, it all depends on the purpose for which the capacities that a third party is provided with are used. Answering this question, however, will not be the objective of this article.

Against this background, our article aims at systematically answering the following questions: What policy instruments does the EU use in empowering others? How are the practices of disempowering and empowering related to each other? And finally, what are the limits of the EU's normative power to empower others?

\section{The International Criminal Court (ICC)}

The idea of establishing an International Criminal Court dates back to the interwar period, but throughout the decades since then it had failed due to a lack of support from states (Fehl, 2004). With the end of the Cold War, the project to establish such a court gained renewed strength. From 1994 to 1997, the UN International Law Commission (ILC) and several preparatory committees drafted a statute for the Court, which served as the basis for the negotiations of the United Nations Diplomatic Conference of Plenipotentiaries in Rome (DipCon) in 1998. At the Rome Conference, the final draft of the ICC Statute was approved by an overwhelming majority of states. The Court itself came into existence in 2002 and subsequently took up its work in The Hague. It is charged with prosecuting perpetrators of genocide, war crimes and crimes against humanity. 
The relationship between the EU and Sub-Saharan African countries on the matter of the ICC changed over time. Therefore, the following part is subdivided into two sections: the drafting stage and ratification and implementation stage of the ICC Statute.

\section{The drafting stage}

The ILC draft statute for the ICC envisaged a strong role of the UN Security Council vis-à-vis the Court. In particular, according to the ILC draft, the Security Council could have suspended investigations on situations being dealt with under chapter VII of the UN Charter. In the negotiations in the Ad-hoc Committee (1995) and the Preparatory Committee (199698), however, opposition formed against this proposal. The so-called Like-minded Group (LMG) emerged, an assembly of some 60 European $^{5}$, African, Latin American and Asian countries and Canada, that pushed for the independence of the ICC from the UN Security Council. The United States increasingly stood alone with its insistence on granting the Security Council a large degree of control over the ICC.

During the drafting stage, the major problem of African states was their lack of expertise and resources. They often were not able to send delegations to the pre-Rome negotiations, or, if they did so, they had only very small delegations that could not cover all working groups that convened simultaneously (Pace 1999: 193). Moreover, they were rarely able to prepare detailed positions on contested issues before the negotiations (Deitelhoff 2004: 13). Therefore, some NGOs seconded experts to a number of African delegations and even paid for them (Glasius 2002: 151).

Apart from the lack of expertise, another problem was the general suspicion against the ICC as a 'western court for Africa' on the part of a number of African countries. Although quite a few African countries were formally members of the LMG, support for an independent ICC was by no means all-pervasive: 'Apart from its Southern part, the continent remains unmotivated by an ICC, because of a lack of information but also because many Africans feel the ICC is created in order to put their heads of state on trial.' (Tine 1998: 11).

In Rome itself, however, a majority of subsaharan African states came to support LMG positions. This had several reasons: Since 1997, LMG states, in cooperation with NGOs, organized a number of regional conferences in order to disseminate information about their plans and proposals for the ICC. The most decisive aspect apparently was that the LMG proposed an independent Court to which all states and their citizens would submit equally, i.e.

5 All EU member states except for France and the UK were members of the LMG. The UK's attitude towards the ICC changed with the 1997 elections, when Labour came to power. France shifted its position only shortly before the Rome Conference began in 1998. 
they envisaged an institutional design for the ICC that was based on reciprocity. From the perspective of Sub-Saharan African countries, this proposal seemed allay the concern that the ICC would evolve as a 'Western’ court for Africa (cf. Deitelhoff 2004: 27). Another reason was that on the sixth meeting of the Preparatory Committee in spring 1998, France, which had previously shared the US' preference for a strong link between the ICC and the UN Security Council, shifted its position and came to support the LMG option of an independent prosecutor for the Court. As a result, a lot of francophone African countries, especially the more oppressive ones that actually had no interest in having an international criminal court at all shifted their positions as well for fear that France would otherwise cut off military training and development aid (Interview NGO, London, 28/02/2007).

\section{The ratification and implementation stage}

Due to the fact that both France and the UK came to support the LMG's positions the rather late in the negotiations, the EU as such had no unified negotiating stance on the Court on the Rome Conference. This changed, however, after the Rome Conference (cf. Deitelhoff 2005). The promotion of the ICC developed into an explicit objective of the EU's Common Foreign and Security Policy (CFSP) (Council of the European Union 2001, 2003). Reference to the promotion of the ICC was also included in the revised Cotonou Agreement (2005). The EU uses a variety of policy instruments in order to promote the ICC in general and to persuade African countries to ratify and to implement the ICC Statute in particular. Generally, the EU is working towards universal ratification of the ICC Statute by raising the issue in multilateral and bilateral frameworks and political dialogues (Council of the European Union 2004). In addition, the revised Cotonou Agreement envisages the provision of legal expertise and assistance in order to help ACP states with the ratification and implementation of the ICC Statute. Curiously, this is framed as 'shar[ing] experience in the adoption of legal adjustments required to allow for the ratification and implementation of the Rome Statute of the International Criminal Court' (Council of the European Union 2005 - emphasis added). Moreover, the EU is funding civil society organizations that promote the ICC. The Coalition for the ICC (CICC), for instance, receives funds within the framework of the European Initiative for Democracy and Human Rights (EIDHR). These detailed measures are linked to and amplified by the provision of more general and diffuse non-material, identity-related rewards. Support for the ICC leads to an increased recognition by the EU, inasmuch as the ICC is said to reflect values that the 'international community should share' (ACP - EU Joint Parliamentary Assembly 2003). As one NGO representative put it: 
'Ratifying the ICC, I think, is for - I maybe mistaken, but I think for a number of countries it is a step towards joining the international community. You know, something that is more and more global and some kind of explanation of international rule of law. Certainly, I mean, as a bid to gain recognition from the EU.' (Interview NGO, Brussels, 06/02/07)

It is hard to say to what extent the EU's efforts to promote the ICC lead to an increased number of African countries ratifying the ICC. Due to the fact that Africa saw a wave of ratifications shortly after the Rome Conference - before the EU adopted the Council Conclusions on the ICC, the influence of NGOs and peer pressure among African states themselves were probably more decisive in the years directly after the Rome Conference. Yet in the case of Chad that ratified the ICC Statute in 2006, even NGO representatives hold that this was mainly due to EU efforts to promote the ICC (CICC, unpublished communication, 2006).

The EU's efforts to promote the ICC gained a particular importance against the background of the US' opposition to the Court. The final draft of the ICC Statute reflected to a large extent LMG positions and thus envisaged a rather independent Court. This induced the US to vote against the Statute. After the ICC was established in 2002, the US pressed third countries to sign and ratify a so-called Bilateral Immunity Agreement (BIA) in order to prevent them from extraditing US citizens to the ICC. In doing so, the US threatened third countries with losing military and economic aid. ${ }^{6}$ The EU reacted by heavily criticizing the US' policy and by drafting legal guidelines on the question of the compatibility of the BIAs with the ICC Statute (Council of the European Union 2002; cf. Scheipers and Sicurelli 2007).

Despite the EU's efforts, only seven out of 49 subsaharan African countries publicly refused to sign a BIA. On the one hand, poor African countries were particularly susceptible to the US' financial pressure (Interview NGO, Brussels 13/02/2007) ${ }^{7}$, on the other, a number of countries simply did not want to jeopardize their good diplomatic relationship with the US (Interview NGO, Brussels 05/02/2007). Although none of the countries that publicly refused to conclude a BIA explicitly referred to the EU guidelines on BIAs, a number of them justified their refusal on the grounds that BIAs would be incompatible with the ICC Statute, thereby arguing in the spirit of the guidelines (du Plessis and Pete 2006: 33; Musila 2005). South Africa and Benin, which lost US military and economic aid subsequent to their refusal

6 In November 2006, President Bush issued a waiver for the economic aid restrictions for some Latin American and African countries, since the effects of both the ASPA and the Nethercutt Amendment were perceived as detrimental to US national interest, in particular in the framework of its counter-terrorism efforts abroad. In addition, Congress adopted the 'John Warner National Defense Authorization Act for Fiscal Year 2007', according to which parts of the restrictions included in the ASPA will be lifted for all states. Cf. Mazzetti (2006).

7 It should be noted, however, that Niger - one of the poorest countries in the world - publicly refused to sign a BIA with the US. As a result, it lost 300,000 \$ aid in 2004 and 2005. 
to sign a BIA, turned to the EU and asked for a compensation of the lost aid (ACP - EU Joint Parliamentary Assembly 2004). This request was supported by some MEPs (ibid.), but eventually the EU's public position on that question was that it would not compensate African states for the lost aid. An official from the EU Commission said that the EU 'didn't want to become complicit in American policy’ (Interview DG Relex, 14/02/2007). In the same vein, a representative from the EU Council explained that the EU 'simply didn't want to play the same game as the US' (Interview EU Council, 12/02/2007). Despite this public line, however, the EU quietly established a framework that allows it to provide extra funds to countries that had lost US aid as a result of their rejection of a BIA. Within the framework of the EU's 'Governance Initiative’ for ACP countries, those countries can apply for additional legal and governance aid that covers at least part of the lost funds (Interview EU Council, 06/02/2007). Regarding the provision of legal assistance, both the EU and individual member states implemented a number of measures geared towards helping African countries with meeting the extensive and highly technical requirements related to the ratification and the implementation of the ICC Statute. They organized and co-organized (together with NGOs) a number of seminars, workshops and conferences in Africa on legal questions surrounding the ICC. In addition, the EU Council established a pool of legal experts that could be seconded to African countries in order to assist with the legal procedures on the spot. While the seminars and conferences were well-received, however, there were almost no requests for the secondment of experts. In comparison to the EU, NGOs seemed to be more successful in the provision of legal assistance in personam. The reason for this may be, on the one hand, that in the field of legal assistance, NGOs had already established close ties to African governments during the drafting stage of the ICC Statute. On the other, the secondment of legal experts by the EU might be considered too intrusive by African states (Interview DG Relex, Brussels, 14/02/2007; Interview African Union, Brussels, 14/02/2007).

Finally, what is striking in the case of EU - Africa relations on the matter of the ICC is the close cooperation between the EU and international civil society organizations. Both the EU and NGOs seem to profit from this close cooperation. The EU draws upon the NGOs' extensive and long experience with promoting the ICC in Africa. NGO representatives brief EU officials on the situation in African countries, i.e. on the prospect of ratification of African countries and on possible obstacles (Interview NGO, Brussels, 06/02/2007). Conversely, the EU enables a number of NGOs to promote the ICC by funding their work. 
The previous sections indicate that the EU acquired a rather clear profile as both an advocate of the ICC and a supporter of African countries in the context of the Court, in particular in the years after the establishment of the ICC. Yet it also shows that the EU's normative power is limited. Firstly, the ICC was no genuine EU project. Rather, the EU's efforts to promote it started late. As a result, it is not easy to tell whether the Sub-Saharan African countries' acceptance and support of the ICC can be credited to the EU or to the work of NGOs. Secondly, the EU's profile became much clearer when the US increased its opposition to the ICC and exerted pressure on African countries to sign BIAs. Yet in this phase it is not clear whether it was the EU's genuine attraction that induced some African countries to refuse to sign a BIA or whether they were alienated by the US' policy rather than attracted by the EU. Thirdly, the EU's normative power is not all-pervasive. A significant number of African countries have ratified the ICC Statute while at the same time having signed a BIA with the US. In those cases, the EU might have been more successful with exerting more pressure in order to induce those countries to refrain from concluding a BIA - it could have threatened to withhold aid on its part, for instance. This option, however, would have been contrary to the EU's self-portrayal as a normative power that does not rely on coercive measures. Finally, a number of Sub-Saharan African countries have not yet signed and ratified the ICC Statute at all. Among them are mainly states with highly repressive regimes, such as Somalia and Sudan, which fear to become the ICC's next target if they signed up to the Court. ${ }^{8}$ This indicates that for the EU's normative power to work, the targeted countries have to accept the norms and values the EU is trying to promote at least to a certaim extent. With notorious human rights violators, the EU's efforts fall on deaf ears.

\section{The Kyoto Protocol}

The negotiations for a Protocol to the United Nations Framework Convention on Climate Change (UNFCCC) begun in 1995 and ended in 1997 with the Kyoto agreement. The Protocol sets binding targets for the reduction of greenhouse emissions solely for industrialized countries. Although exempted from reducing emissions, developing countries that ratify the agreement are required to implement measures to address climate change. Several conferences of the UNFCCC followed the signature of the Kyoto Protocol in the attempt to identify strategies to achieve the goals of the Kyoto Protocol and set the targets for the post-Kyoto period. The conference held in Buenos Aires in 1998, for example, defined the commitments for the implementation of the Kyoto Protocol, which finally entered into force

8 The ICC currently investigates the situation in Darfur, Somalia, but this is due to a referral of the UN Security Council and is contrary to the preference of the government in Khartoum. 
in 2005. As of December 2006, 166 states have ratified the Protocol, while the US remains the most crucial opponent of the agreement.

\section{The drafting stage}

The EU proved influential in the negotiations for the Kyoto Protocol and contributed to shaping the positions of the group of Sub-Saharan countries.

The major cleavage emerging during the negotiations for the Kyoto Protocol was that between the EU and the US. The EU proposed a 'differentiation mechanism' based on the principle of common but differentiated responsibilities. This mechanism implies a different level of commitment for industrialized and developing countries. According to the EU, developing countries should not be required to cut their emissions, since limitations of industrial production would undermine their economic development. At the same time, the EU suggested that the Protocol set the basis for the voluntary use of alternative means of production in developing countries that are not considered harmful for the climate. The idea behind the differentiation mechanism is that it is the only way to have developing countries on board in the attempt to solve the problem of global warming and to intervene in the process of industrialization of developing countries in order to prevent damages for the environment. The US, on the contrary, was in favor of a uniform universal commitment, meaning the imposition of emissions cuts on both industrialized and developing countries. The US fears that the differentiation mechanism, by contributing to the empowerment of raising economies such as China and India, would affect its relative economic power. Moreover, during the Kyoto negotiations, the US argued against the EU proposal of binding commitments for emissions cuts and suggested market-based and voluntary instruments as solution of the problem of climate change (flexibility mechanisms).

The differentiation mechanism was included in the Treaty as the result of a compromise between the EU and the US. The EU recognized the drawbacks of a purely regulatory approach in the Fifth Environmental Action Programme in 1995 and accepted the inclusion of market-driven instruments in the Protocol (Damro and Mendèz 2003). The US, in turn, accepted the inclusion of the differentiation mechanism proposed by the EU.

The group representing developing countries in the Kyoto negotiations gave full support to the EU proposal, since they considered it coherent with their development interest. As with the case of the ICC, Sub-Saharan African countries did not have a clear-cut position during the first stage of the negotiations, since they lacked expertise. Most of these countries did not even have the resources to participate in international negotiations and those countries who 
did participate were represented by a very small number of officials (Interview NGO, Brussels, 14/02/2007). Because of their small delegations, it was not possible for them to take part in all the sub-groups the Kyoto meeting was split into. South Africa stands out as the most prominent in terms of environmental expertise as compared to the other Sub-Saharan African states. Nevertheless, even the contribution of South Africa was not relevant in the negotiations to draft the Kyoto Protocol. The South African government started to be influential just recently, during the 2005 negotiations for the UNFCCC agreement on 'Sustainable development policies and measures’ (Interview European Commission, Brussels, 09/02/2007). The lack of involvement of South Africa in the drafting stage of the Kyoto Protocol was linked to the fact that until the mid-1990s, South Africa was marginalized in the international negotiations because of its Apartheid regime. The democratic elections in South Africa in April 1994 opened the period of normalization of the relations between South Africa and the UN. So in 1995, when the negotiations for the Kyoto Protocol started, South Africa had just started playing an active role in the UN and had not yet gained the status of a key partner for the negotiations (Interview NGO, Brussels, 07/02/2007).

Thus, Sub-Saharan countries had to rely on the expertise of Western NGOs and of industrialized countries to define their position in the negotiations on climate change. In the first stage of the Kyoto negotiations, the group of Sub-Saharan countries supported the proposal of the British NGO Global Commons Institute of the 'contraction and convergence mechanism', which distributes rights and obligations by establishing per capita emission rights for all countries on the basis of the principle equity (Interview NGO, Brussels, 14/02/2007). This mechanism would require industrialized countries to make substantial cuts in their emissions and allow industrializing countries to increase theirs within the equal level per capita objective. In the Kyoto negotiations, Sub-Saharan countries supported the EU differentiation mechanism, since it was the proposal that appeared closer to the contraction and convergence mechanism. The differentiation mechanism shared with the contraction and convergence scheme the idea of the need for differentiated responsibilities of developing and developed countries.

After the Kyoto negotiations, the difference between the EU and the US positions on climate change crystallized and the transatlantic cleavage contributed to polarizing the international debate on global warming. During the fourth UNFCCC Conference of the parties in Buenos Aires (02-13 November 1998) three distinct groups emerged. The first group was the socalled 'umbrella group', comprising the US and other states (Australia, Canada, Iceland, Japan, New Zealand, Norway, the Russian Federation and Ukraine), opposing binding targets 
and preferring flexible market based mechanisms. The second group was composed by the EU (comprising 15 member states at that time), plus Switzerland and the East European Countries, who preferred stricter rules for emissions trading to make more ambitious targets available after 2012 (the deadline for the Kyoto commitments). The third group was composed of developing countries and was named 'the G77 plus China Group'. This group was clearly closer to the EU position than to the US, since most of them were in favor of a reduced use of flexibility mechanisms. Latin-American countries, which shared the US proposal of an extended use of those mechanisms, were exceptions within this group (Torvarger 1998). The sub-group of Sub-Saharan African countries, in general, supported the European position on climate change policy.

\section{The ratification and implementation stage}

While the EU did succeed in influencing the positions of Sub-Saharan countries in the Kyoto negotiations, the attempt to push these countries to ratify and implement the Protocol had mixed results.

After having ratified the Kyoto Protocol, the EU tried to persuade other Parties to do the same. In this attempt, the EU focused particularly on Russia, since Russia's ratification was essential in reaching the number of ratifications needed for the enforcement of the Protocol (the number of industrialized countries producing 55\% CO2) (Walters 2004). Although ratification by Sub-Saharan countries was not crucial for the enforcement of the Protocol, the EU tried to persuade them to ratify the agreement.

A major difference between the EU and the US in their relations with Sub-Saharan Africa was that the EU tried to include them in a multilateral effort to tackle the problem of climate change, while the US did not propose any alternative agreement to the Sub-Saharan states. In July 2005, the US did propose a multilateral agreement to fight climate change, the 'AsiaPacific Partnership on Clean Development and Climate', which allows the parties to the agreement to set their goals for cutting emissions individually. This voluntary partnership, though, involves only Australia, China, India, Japan and the Republic of Korea and does not include African countries. The only bilateral agreement proposed by the US that took into account the African continent was that with South Africa, which the US government considers 'a key leader among developing countries on issues such as climate change' (US Department of State 2007). This cooperation, nevertheless, did not prevent South Africa from ratifying the Kyoto Protocol. 
So far, 40 out of 49 Sub-Saharan African countries have ratified the agreement. According to representatives of the ACP Secretariat and of the African Union delegation in Brussels, the reason why nine African states have not ratified the Protocol is the slow legal procedures that ratification of international treaties requires in those countries. A representative of the African Union office in Brussels argued that ratification of international treaties in African states is cumbersome, especially in the states where ratification requires parliamentary approval (Interview African Union, Brussels, 13/02/2007). These problems are particularly evident with respect to low political salience issues for the African states facing crucial development problems, such as environmental protection. Unlike the ICC case, political opposition to the Kyoto Protocol, therefore, does not appear to be a relevant explanation for the fact that some Sub-Saharan African states have not ratified the Kyoto Protocol.

Because of the cost-free commitment to the Kyoto Protocol for developing countries and because of the lack of a strong US opposition, one may argue that it was relatively easy for the EU to persuade developing countries to ratify the Protocol. At the same time, though, there is evidence that the EU succeeded, at least partially, in the attempt to promote ratification of the Protocol in the Sub-Saharan area, since it was able to construct a positive image of the EU climate change policy in the eyes of representatives of Sub-Saharan African countries. Representatives of African institutions argue that in general the African countries share with the EU the idea of the need to fight the problem of climate change through binding commitments. The representatives of the ACP Secretariat and of the African Union delegation in Brussels working on environmental matters stressed that most of the African countries that have ratified the Kyoto Protocol did so because they believe that there is a need to reduce the process of global warming, which, through increasing desertification in Africa, has dangerous effects on African agriculture (Interviews African Union, Brussels, 13/02/2007 and to ACP Secretariat Headquarters, 07/02/2007). They believe that the EU approach is more appropriate to this purpose than the American approach. According to a representative of the ACP secretariat, 'the US is only thinking for itself. The US believes that climate change can be tackled nationally. It relies too much on the Environmental Protection Agency in the solution of global problems. Plus, the US is one country, although influential, while the EU is a powerful block' (Interview ACP Secretariat Headquarters, 07/02/2007). A number of reasons certainly contributed to ratification of the Kyoto Protocol by most of the African states and if the EU pressure was successful, it was probably because of one of these reasons. A success of the EU attempt to build its image as a normative power appears from the correspondence between the rhetoric of EU authorities and the perceptions of Sub-Saharan authorities. The 
self-representation of the EU as the leader of the Kyoto Protocol and the depiction, by the EU authorities, of the US as the major opponent (Scheipers and Sicurelli 2007) appears to be largely shared by Sub-Saharan African countries.

Despite this success, the EU's attempt to persuade African countries to ratify the Protocol is not without contradictions. In the attempt to persuade the developing countries that have not ratified the Protocol to do it as soon as possible, the EU has applied a conditionality scheme. In June 2005, the EU adopted the 'GSP Plus' program, stating that it would provide development aid within the Generalized System of Preferences under the condition that developing countries have ratified a number of agreements, including the Kyoto Protocol. According to a representative of a Brussels based NGO, Climate Action Network, this program has positive implications. It can be considered a 'structural aid' measure, since it helps developing countries to meet international obligations. 'Through this program, the EU helps African countries to develop their capacities to be involved in the negotiations.' (Interview NGO, Brussels, 07/02/2007). At the same time, though, the program has raised suspicions among representatives of the African states, who consider the EU conditions an expression of 'new colonialism’ (Interview ACP Secretariat Headquarters, 08/02/2007).

Following the proposal of the European Commission, on 22 November 2004, the General Affairs and External Relations Council adopted an Action Plan on Climate Change in the Context of Development Cooperation. In the framework of this plan, the EU aims to assist EU partner countries in meeting the challenges posed by climate change, in particular by supporting them in implementing the Kyoto Protocol and providing them with funds to tackle the problem of climate change. Unlike the GSP Plus program, this plan does not impose conditionality criteria. The Council of the EU will review the implementation of the Action Plan in 2007 following the first biannual report, and will consider further action beyond 2008. This research project aims to provide an assessment of the implementation of the Plan and to identify resources for and the challenges for the EU strategy to assist ACP countries in the fight against climate change. It is too early to assess the results of this plan. Nevertheless, problems in testing the implementation of this plan have already emerged. A first problem emerged is that most African countries do not publish their implementation records, which makes monitoring the final destination of EU funds a difficult task.

The EU has continued to provide expertise to Sub-Saharan countries after the enforcement of the Kyoto Protocol in order to give them the resources to tackle the problem of climate change. In this perspective, in 2005 the EU contributed to the UN project on 'Advancing capacity, partnership and knowledge to support climate change adaptation in Africa and Asia' 
providing funding from the European Development Fund. Moreover, the EU has established a dialogue with the two institutions representing the African states in Brussels, the ACP secretariat and the African Union, in order to include the African countries in the EU-lead 'coalition of the willing' in the fight against global warming (Europaworld 2002). One of the outcomes of this dialogue is that climate change has entered the agenda of the meetings of the African Union. At the Eighth Ordinary Session of the Assembly of the African Union, held in Addis Ababa on 29-30 January 2007, the African Union drafted a document on 'Climate Change and Development', stressing the need to link the two policies. Also the ACP Secretariat has started to consider climate change among its priorities. Although not all of the ACP states have ratified the Kyoto Protocol, the first meeting of the ACP Ministers of the Environment held in Brussels on 10 December 2004 showed a general commitment to the Kyoto targets. The ministers welcomed the imminent coming into force of the Kyoto Protocol and 'they urged countries that had not yet done so to ratify the Agreements without further delay' (ACP Secretariat 2004). In June 2006, the EU and the ACP countries opened a debate on global warming, which lead to the 'Joint ACP-EU Declaration on Climate Change and Development'. These meetings show that climate change has become an increasingly relevant issue for Sub-Saharan African countries and that the ACP and the AU are considered interlocutors for the EU in the implementation of the Kyoto commitments and in drafting post-Kyoto commitments.

\section{EU normative power through empowering}

The relationship between the EU and Sub-Saharan Africa provides an arena for the process of EU identity building. The EU's self-representation as the force for good is an expression of its attempt to construct its image as a normative power. In order to promote its norms internationally, the EU tries to build an image of itself as an altruistic actor. In this framework, the EU-Africa relations are an excellent case to investigate EU identity building, since the EU has traditionally referred to the African continent through a solidarity-based rhetoric.

While the process of national identity building in some of the EU member states - notably Germany and Italy - had largely anticipated the process of state building through asserting the existence of a pre-political community based on linguistic and ethnic ground, the process of identity building in the EU is going through an opposite path (Fabbrini 2007). The process of EU polity building started 50 years ago, but the construction of the EU identity is far from being accomplished. While nation states tend to construct their identity on the basis of shared 
perceptions of common belonging, the EU has to find alternative means to build its identity. Foreign policy provides the EU with a ground to fill this identity-gap. Besides 'self representation', the process of identity building through external relations comprises two further dimensions: the actual behavior of the actor (foreign policy) and the perceptions of relevant others. This article has analyzed the EU alleged normative power in action. Consistent with Lucarelli and Manners' (2006) assumption, we argue that looking at what the $E U$ does may contribute to - although it does not exactly correspond to - what the EU appears to be in the eyes of the others, the external image of the EU.

In sum, in the cases of the ICC and of the Kyoto Protocol, the EU exerts normative power in its relations to Sub-Saharan African countries at three different levels. At all levels, the EU's policy is intended to empower African countries:

- Identity level: The ratification of the ICC Statute and the Kyoto Protocol by African countries results in an increased recognition by the EU.

- Knowledge level: In the case of the ICC, the EU provides legal technical expertise about the ICC and the requirements for ratifying and implementing its Statute in the framework of conferences and seminars. Legal assistance was also provided in an indirect way, i.e. by funding NGOs. Regarding the Kyoto Protocol, the EU supported the UN-run knowledge transfer program on climate change.

- Material level: In the case of climate change, the EU made the provision of parts of its development aid conditional on the ratification of the Kyoto protocol. In the ICC case, the EU partly compensates African countries refusing to sign a BIA with the US for lost aid. Curiously, whilst the first two levels of empowering are part of the EU's self-depiction, the level of material rewards or, rather, compensations is excluded from the EU's public selfportrayal in the case of the ICC. Although EU officials saw the pragmatic need for compensation measures, they were not made public. Thus, in the construction of its external relations, the EU emphasizes non-material measures and at times keeps quiet about the material ones. This self-portrayal is in line with the 'emphasis on the normative power of nonmaterial exemplification found in the contagion of norms through imitation and attraction' (Manners 2006b: 176). It indicates, however, that the EU is at times merely 'miming' normative power, since self-portrayal and outcomes of EU actions differ.

The attempt to 'empower' Sub-Saharan countries in the ICC and Kyoto cases is a manifestation of the process of identity building in the framework of a solidarity-based normative power. By promoting reciprocal institutional arrangements and shared but differentiated responsibilities, and by assisting Sub-Saharan states in their participation in 
international negotiations and in the ratification and implementation of international treaties, the EU has committed to empower states that are typically considered weak parties.

This attempt to empower Sub-Saharan Africa is related to the EU attitude towards the US. The way in which the EU relates to the relevant 'others' in its external relations sheds light on the type of actor the EU claims to be. While the EU authorities' rhetoric shows an attempt to weaken the US in the international eyes by depicting it as the major opponent of international law and as a laggard in fulfilling international obligations, the way in which the EU relates with Sub-Saharan Africa shows the opposite project, that of depicting developing countries as partners in the international negotiations and as potential allies in the implementation of international law. The EU is building its identity through providing Sub-Saharan countries with legitimacy as partners and recognition of their own identity as rule-of-law minded states, as states sharing the core values of the international community. Although opposite processes, both practices of othering (disempowering and empowering) are expression of the same attempt of the EU to appear as the force for good.

The EU's international behavior appears largely consistent with its identity building process, but an assessment of the EU's attempt to construct its image as a normative power leads to mixed results. Both the ICC and the Kyoto cases show that the EU has been able to build its profile as an advocate of international law and as a supporter of developing countries. In this respect, the EU's self-representation seems to match its external image. Nevertheless, in both cases, limits in the EU's normative power become evident. In the ICC case, it is unclear to what extent the EU exerted influence on the Sub-Saharan African countries that ratified the ICC Statute, since the promotion of the ICC is not only a EU project. Moreover, several African countries that have ratified the ICC have also signed BIAs with the US. Thus, if the EU faces a competing power threatening to use coercive measures in order to achieve its objectives, it is difficult for the EU to prevail. Finally, the EU's normative power in the ICC case proved to be limited when confronted with hard cases, since many African countries known for human rights violations have not ratified the ICC. In the case of climate change, most Sub-Saharan African countries have ratified the Kyoto Protocol and the representatives of Sub-Saharan countries in the ACP Secretariat have started to carry out joint projects with the EU to tackle the problem of climate change. Nevertheless the EU is facing problems in testing the effectiveness of the implementation of the Kyoto Protocol in developing countries. Moreover, the use of conditionality measures by the EU to promote the implementation of the Kyoto Protocol has raised resistance and criticism among the African authorities. 
The limits of the EU normative impact may affect its relationship with third countries in the long run and, ultimately, it may undermine its international identity as a normative power. At the same time, though, it is worth noticing that the relationship between rhetoric, actions and results is not straightforward. Consistency between rhetoric and actions is not easy to measure empirically and the results of the EU actions can be interpreted differently. The ambitious (or utopian) self-representation of the EU, the practices of dialogue with developing countries and formation of broad coalitions within the international organizations may prove a powerful instrument for the EU to reinforce its image as a normative actor.

\section{Conclusion}

The relationship between the EU and Sub-Saharan Africa in the fields of human rights and environmental protection provides evidence that the EU is constructing (or is trying to construct) its identity as a normative power.

In its attempt to persuade Sub-Saharan African states to ratify the ICC Statute and the Kyoto Protocol the EU shows its commitment to diffusing the norms of human rights and environmental protection beyond its borders. The policy instruments the EU has selected to this purpose are consistent with the model of a normative power. The EU has provided SubSaharan countries with identity, expertise and financial resources to take part in international negotiations. Moreover, the EU has tried to empower African states through proposing the principle of reciprocity in the ICC negotiations and the principle of common but differentiated responsibilities in the fight against climate change. These instruments, aimed at improving the international position of these countries, have helped the EU to build its image of solidaritybased normative power.

Empowering developing countries appears as a dimension of the EU's identity. This dimension flanks a second dimension, that of disempowering. While the EU tries to empower developing countries as actors in the international relations, it engages in disempowering the US, depicting it as the opponent of international law. Empowering and disempowering are two aspects of othering, a central process in identity construction.

Thus the instruments the EU uses in its external relations confirm the thesis of normative power Europe. Nevertheless the attitude of the EU to material resources of influence and the results of EU foreign policy provide a mixed image of the EU. As far as the use of material resources is concerned, the EU does not openly recognize the use of compensation measures and it uses conditionality measures to diffuse its norms, which shows possible contradictions between how the EU represents itself and what the EU does. If these contradictions are 
considered relevant internationally, they may affect the international image of the EU. With respect to results, the EU succeeded in affecting the position of the group of developing countries in the negotiations for the Kyoto Protocol, while in the negotiations for the ICC this influence appears less evident. Finally, in the case of the Kyoto Protocol the EU is facing problems in testing the effectiveness of the implementation of international environmental law in Sub-Saharan Africa.

What the EU policy with respect to the ICC and climate change shows, therefore, is that there is evidence of EU normative commitment, which distinguishes the EU for its attempt to spread norms internationally by empowering developing countries. A closer look at what the EU does and what the EU achieves, though, reveals that the EU is still far to play the role of an effective normative power. 
References

ACP-EU Joint Parliamentary Assembly (2004) 'Daily Notebook. Eigth Session', The Hague, 23 November 2004.

ACP-EU Joint Parliamentary Assembly (2003) 'Resolution on the International Criminal Court (ICC)’, Brazzaville, 03 April 2003.

ACP Secretariat (2004), 'Commuinque by the First Meeting of the ACP Ministers of the

Environment', Brussels, 10 December

http://www.acp.int/en/press_releases/environnementcmnq_en.html

Barnett, M. and Duvall, R. (2005) 'Power in International Politics', International Organization, Vol. 59, No. 1, pp. 39-75.

Council of the European Union (2005) 'The EU and Africa: Towards a Strategic Partnership', Brussels, 19 December 2005.

Council of the European Union (2004) 'Action Plan to Follow-up on the Common Position on the International Criminal Court’, Brussels, 04 February 2004.

Council of the European Union (2003) 'Council Common Position of 16 June 2003 on the International Criminal Court’ (2003/444/CFSP), Brussels, 16 June 2003.

Council of the European Union (2002) 'Council Conclusion on the International Criminal Court (ICC) and the draft US American Servicemembers' Protection Act, ASPA', Brussels, 17-18 June 2002.

Council of the European Union (2001) 'Council Common Position of 11 June 2001 on the International Criminal Court' (2001/443/CFSP), Brussels, 12 June 2001.

Damro, C. and Méndez, P. L. (2003) 'Emissions Trading at Kyoto: from EU Resistance to Union Innovation', Environmental Politics, Vol. 12, No. 2, pp.71-94.

Deitelhoff, N. (2004) 'The Transnational Construction of Legal Norms and Institutions: The Interaction of Law and Politics in the Development of the International Criminal Court', Paper presented at the Fifth Pan-European International Relations Conference, The Hague, 9-11 September 2004.

Deitelhoff, N. (2005) Europa vor Gericht. Die EU-Außenpolitik und der International Strafgerichtshof (Frankfurt/Main: Hessische Stiftung Friedens- und Konfliktforschung).

Diez, T. (2005) 'Constructing the Self and Changing Others: Reconsidering "Normative Power Europe”, Millennium: Journal of International Studies, Vol. 33, No. 3, pp. 613-36. 
Diez, T. (2004) 'Europe's others and the return of geopolitics', Cambridge Review of International Affairs, Vol. 17, No. 2, pp. 319-35.

du Plessis, M. and Pete, S. (2006) The International Criminal Court and Serious Crimes Committed by Peacekeepers in Africa (Pretoria: Institute for Security Studies).

Duchêne, F. (1972) ‘Europe’s Role in World Peace’. In Mayne, R. (ed.) Europe Tomorrow: Sixteen Europeans Look Ahead (London: Fontana).

EuropaWorld (2002) 'World Summit Renewable Energy Goals to be Delivered by EU Coalition’, 6 September 2002, http://www.europaworld.org/week95/worldsummit 6902.htm.

Hill, Christopher (1990) 'European Foreign Policy: Power Bloc, Civilian Model - or Flop?’. In Rummel, R. (ed.) The Evolution of an International Actor (Boulder, CO: Westview Press).

Fabbrini, S. (forthcoming, 2007) Compound Democracies. Why the United States and Europe Are Becoming Similar (Oxford: Oxford University Press).

Glasius, M. (2002) 'Expertise in the Cause of Justice: Global Civil Society Influence on the Statute for an International Criminal Court'. In Glasius, M., Kaldor, M. and Anheier, H. K. (eds). Global Civil Society Yearbook 2000 (Oxford: Oxford University Press).

Lucarelli, S. and Manners, I. (2006) (eds.) Values and Principles in European Union Foreign Policy (London: Routledge).

Manners, I. (2006a) 'Normative Power Europe Reconsidered: beyond the Crossroads', Journal of European Public Policy, Vol. 13, No. 2, pp. 182-199.

Manners, I. (2006b) 'The European Union as a Normative Power: a Response to Thomas Diez’, Millennium: Journal of International Studies, Vol. 35, No. 1, pp. 167-180.

Manners, I. (2002) 'Normative Power Europe: A Contradiction in Terms?', Journal of Common Market Studies, Vol. 40, No. 2, pp. 235-58.

Maull, H. W. (1990) 'Germany and Japan. The New Civilian Powers’, Foreign Affairs, Vol. 69, No. 5., pp. 91-106.

Mazzetti, M. (2006) 'U.S. Cuts in Africa Aid Said to Hurt War on Terror’, New York Times, 23 July 2006.

Musila, D. (2005) 'The US Must Stop Piling Pressure on Kenya', The Daily Nation (Kenya), 16 May 2005.

Pace, W. (1999) 'The Relationship between the International Criminal Court and NonGovernmental Organizations'. In Lee, R. S. (ed.) The International Criminal Court: The Making of the Rome Statute, pp. 189-211 (The Hague: Kluwer). 
Rumelili, B. (2004) 'Constructing Identity and Relating to Difference: Understanding the EU’s Mode of Differentiation', Review of International Studies, Vol. 30, No. 1, pp. 27-47.

Scheipers, S. and Sicurelli, D. (2007) ‘Normative Power Europe: a Credible Utopia?’, Journal of Common Market Studies, Vol. 45, No. 2, pp. 435-457.

Sjursen, H. (2006a) 'The EU as a “Normative” Power: How Can this Be?', Journal of European Public Policy, Vol. 13, No. 2, pp. 235-251.

Sjursen, H. (2006b) 'What Kind of Power?', Journal of European Public Policy, Vol. 13, No. 2, pp. 169-181.

Tine, A. (1998) 'Africa and the International Criminal Court', The International Criminal Court Monitor, No. 7, p. 11.

Torvanger, A. (1998) 'The state of the Kyoto Protocol negotiations. After the fourth UNFCCC Conference of the Parties (COP4) in Buenos Aires', Policy Note, 2-13 November 1998, http://www.cicero.uio.no/media/51.pdf.

US Department of State (2007) 'South Africa, Background Note of the Bureau of African Affairs’, April 2007, http://www.state.gov/r/pa/ei/bgn/2898.htm.

Wæver, O. (1995) 'Securitization and Desecuritization'. In Lipschutz, R. D. (ed.), On Security (New York, NY: Columbia University Press).

Walters, G. (2004), 'Kyoto, WTO Deals Hang in Balance’, in Moscow Times. 